\title{
Culturally-endorsed Leadership, Social cognition, and Entrepreneurial Orientation: An Empirical Inquiry
}

\author{
Saima Haroon \\ Karachi University Business School (KUBS), University of Karachi \\ KU Circular Road, University of Karachi, Karachi, Pakistan \\ E-mail: saimaharoon0202@gmail.com \\ Dr. Danish Ahmed Siddiqui \\ Karachi University Business School (KUBS), University of Karachi \\ KU Circular Road, University of Karachi,Karachi, Pakistan \\ E-mail: daanish79@hotmail.com
}

Received: December 12, 2019 Accepted: December 23, 2019 Published: December 30, 2019

doi:10.5296/bms.v10i2.16156 URL: https://doi.org/10.5296/bms.v10i2.16156

\begin{abstract}
Entrepreneurial orientation can not only be influenced by leadership, culture, but also through social cognition induced through Job Demands and Resources. Moreover, higher Entrepreneurial orientation could further lead to job satisfaction. These intricate relationships were never explored before. Therefore, we proposed a theoretical framework combining (Stephan \& Pathak, 2016) and (Ralph Kattenbach, 2018) models, and modifying them to include the concept of Job satisfaction. Stephan \& Pathak (2016) investigated the impact of Culturally-endorsed implicit Leadership Theories (CLT) on individual entrepreneurship. CLTs is a concept of culture-level build on individual-level implicit leadership theory (ILT) proposed by (Robert G. Lord, 1991). (Ralph Kattenbach, 2018) modified (Bandura, 1997) social cognitive theory (SCT) to include Entrepreneurial orientation. SCT itself was a modified version of Job Demands-Resources Model proposed by (Demerouti, 2001). Empirical validity of the proposed theory was established by means of a survey based on close ended Likert scale type questionnaire that collected data from 200 corporate sector employees based in Karachi. It was later analyzed using structured equation modeling and confirmatory factor analysis. This result showed that both cultural factors i.e. Uncertainty
\end{abstract}


Avoidance and Collectivism have a significant and positive influence on both Self-Protective and Charismatic leadership. However, the effect of leadership on entrepreneurial orientation (EI) was not empirically significant. Similarly, the effect of both social cognitive factors i.e. Job Demand and Job resource on EI was positive and significant. EI and job demand had an insignificant effect on job satisfaction. However, job resource has a significant positive impact. This imply that job resource factors have a direct influence on EI as well as Job Satisfaction. But EI itself has no direct link with job satisfaction of employees. Hence, mapping and evaluating a culture of organization in consolidation with its employees' job demand and resource factors may lead to higher job satisfaction.

Keywords: culture, Culturally-endorsed Leadership, social cognitive theory, entrepreneurial orientation, leadership, job demand, job Resources, job satisfaction.

\section{Introduction}

\subsection{Background of the Study}

An abiding question is: why a minority of individuals decided to accomplish potential opportunities. (Venkataraman, 1997). Lots of research have provided observations into the influence of economic, individual cognitions and institutional environment. (Bird Barbara, 1988). But a spreading assumption is here that factors like culture can play a very important yet partially studied role in intention of entrepreneurship and job satisfaction of employees. (GEORGE Gerard, 2002). Culture can have impact on entrepreneurial intentions of individuals by determining legitimacy, fostering shared meanings (MacIntosh, 1990) and conditioning them to initiate entrepreneurship. (Dana, 1995). Still, even though all these symptoms that indicate the importance of culture, a theoretical understanding of how it influences Entrepreneurial Intentions is still ambiguous (Thornton, 2011).

Drawing upon the notion of 'culture-entrepreneurship-fit' (Tung, 2019), they foresee those cultures that give value to key facet of entrepreneurship, like the eagerness to bear individual competitive actions and uncertainty to enable entrepreneurship. Researchers argued that a culture that is more welcoming of uncertainty would be more likely to abide the individual risk taking intrinsic in entrepreneurial venture development (Neupert, 2003). A helpful organizational culture leads job satisfaction, motivation and work ethic. These are factors that indicates high performance of employees which will results in high organizational performance. (Ilham, 2018).

Cultural values are the notion of ideal leadership that frame cultural expectations, leaders act in line with the same expectations. Consecutively, organizations operate well when their CEOs' behaviors coordinate with the leadership ideals prevails in their cultures. A good culture of organization has a very positive impact on employee's performance. In fact, advancement of such culture, commitment and sense of identity will facilitate and increases the strength of the organization. (Stephan \& Pathak, 2016). On the relation between job satisfaction and organizational culture researchers proposed that a dynamic working environment encourage the construction of a definite organizational culture and employees' job satisfaction (Schneider, 
1975). Additionally, they indirect that employee's job satisfaction increases as they promote to higher job levels (Corbin, 1977).

In recent years, several studies have used an integrative approach in combining the explanatory value of job characteristics from the JD-R model with a different approach concerning the impact of individual characteristics like Individual Entrepreneurship (Vink, 2011). The line of research has shown that personal resources (e.g. self-efficacy) have a substantial impact on the job characteristics/well-being link. However, the precise function is not clearly determined. Personal resource act as a mediating role that effects job resources as well as for a moderating and mediating impact on the effect of job demands. (Brenninkmeijer, 2010).

It seems obvious that work-related orientations should have a strong influence on the impact of job conditions proposed by the JD-R model. However, there is still little evidence on how these conditions influenced by culture of the organization, but still a room of research is empty on how they lead to the individual entrepreneurship and how these job conditions will affect job satisfaction of employees in Karachi, Pakistan.

\subsection{Problem Statement}

With the huge number of institutions and worldwide, it is common that the employee's well-being in their workplaces has become a matter of theoretical interest and expanded research. A firm's well-being is determined as the way in that its work function and quality are perceived by its employees (Warr, 1992). This includes the individual's mental and physical condition/ health, social well-being and sense of happiness, these are all associated with job satisfaction (Grant, 2007). It has been observed that in the organizations, employees who have developed negative attitudes to their working conditions, colleagues and top management, tend to feel less committed to their job and becoming more stressful, compel to leave the organization and experience high levels of pessimism and disappointment. Because of this, expert's and company manager's interest turned to this study mechanism to boost up employee's job satisfaction and deal with their emotional burnout and occupational stress (Dimitrios Belias, 2014).

There is a considerable need to appraise those psychosocial factors at work which improve employee's well-being. psychosocial factors at work and improve well-being of employees. Apparently, bad working conditions and burned out employees are linked with, for example absence, sickness, accidents and injuries, poor performance and less productivity, while the reverse is absolutely true for employee level of satisfaction and good working conditions. So eventually, employee well-being and psychosocial factors interpret into organization financial business growth and outcomes along with high employee job satisfaction (Schaufeli, 2017).

While factors, including job demand and resources have an influence on job satisfaction of employees, present studies offer some information in that individuals are more similar than others to whom organizational factors do affect them like opportunities for innovation and EO in doing work and work environment. Employees who develop an EO make a more 
effective use of job resources and cope better with job demands, which leads to higher job satisfaction (Ralph Kattenbach, 2018).

Much of the literature present about factors influence employee's job satisfaction, whereas research studies imply that organizational factors have impact on employee's job satisfaction. (Brenda L. Mak, 1999), these studies suggested little information on why some individuals affected more by these factors than others. Owing to the job satisfaction values which are very stable over time (Beyard, 1997) and personality related differences, it can be said that differences in the workplace, e.g. working conditions, the management conduct of superiors or the conduct of colleagues, cannot fully explain job satisfaction (Wegge, 2006). Job satisfaction is assumed to be also characterized by personality traits (Judge, 2001) and entitlement mentalities (Wegge, 2006). Studies on the individual impact are scarce and theoretically not elaborated. EO deals with an individual's personal characteristics or attitudes that might increase the likelihood of getting involved in entrepreneurial activities (Bolton D. L., 2012). Thus, an EO might influence how individuals perceive their working conditions. Consequently, employees with EO are more prepared to cope with job demands and report less exhaustion. Such employees handle or perceive high job demands less negatively, without this having any influence on job satisfaction. (Süß, 2011).

We use two models to interlink culture, entrepreneurial orientation of employees and JD-R model that lead to betterment of organization environment and employee's job satisfaction. We offer a better understanding by including a moderator i.e. entrepreneurial orientation. We posit that individual's despite of having all job resources the higher the desire for innovation, which here we term as entrepreneurial orientation of employee may lead to more job satisfaction.

\subsection{Gap Analysis}

Chao et al. (1994) found that employees' understanding of the goals, values and politics of their companies were positively and significantly related to job satisfaction. They also indicated that the congruency between employee characteristics and the characteristics preferred by management led to job satisfaction. (Chao, 1994). Holland (L., 1985) argued that congruency must exist between a person's interests, preferences and abilities, and organizational factors in the work environment in order to achieve maximum performance. Walsh and Furnham (Furnham, 1990), concluded that congruent environments give job satisfaction because people are among others with similar values and tastes.

Furthermore, Culture could also have some effect on job satisfaction. Cross cultural studies have found that employees in collectivistic countries, especially Japan, report lower job satisfaction overall (DeBoer, 1978).

While job satisfaction studies are pervasive in western societies, however, the effects of cultural variables and individual entrepreneurship on job satisfaction of employees are not discussed in any studies. While there are quite a number of studies investigating the relationships between managerial practices such as TQM, quality circles and cultural 
variables like paternalism and collectivism in organizations (Aycan, 2000), there are no studies about the simultaneous influence of culture, individual entrepreneurship and job factors i.e. job demand and resources on job satisfaction.

This study tries to bridge the gap by engaging a unique methodology to explore job satisfaction and entrepreneurial intention of employees through the existence of an intermediate mechanism.

\subsection{Research Objectives}

The purpose of the paper is to explain the impact of EO and organizational culture on employee's job satisfaction. Specifically, this study aims to investigates the influence of culture values, leadership styles, job demand factors like (Emotional Strain, Workload, Cognitive workload and Role Conflict); job resource factors like (Job Autonomy, Growth Potential, Social support, Feedback) on Individual Entrepreneurship and job satisfaction.

For this, a large-scale literature review in different research fields, and a survey conducted by employees of Karachi. In this research, the author's goal also to acquaint dark aspects of relevant literature, like innovation and individual entrepreneurship and its impact on job satisfaction.

\subsection{Research Question}

- To understand the impact of culturally indorsed leadership theories on Individual Entrepreneurship.

- To understand the relation of Culture Values and Style of Leadership.

- To understand the relation of Individual Entrepreneurship and Job Satisfaction.

- To understand the impact of Job Demand and Job Resource on Individual Entrepreneurship.

- To understand the impact of Job Demand and Job Resource on Job Satisfaction.

\subsection{Significance}

For years company's managers believe that an employee will bring high performance if he is satisfied with his job. (Gomes, 2000) articulated that an employee's job satisfaction with his work is linked to absenteeism, his turnover intentions, working age, size, level and position of organization. Though, this study is very useful for employees of the organization to know how cultural values i.e. Uncertainty avoidance and in-group collectivism effects on their style of leadership, how factors like job demand and job resource increase their entrepreneurial orientation and how it leads to their job satisfaction.

This research contributed both conceptually and practically in the fields of business/ corporate sector. This research findings favor that entrepreneurial orientation are linked to cultural leadership. For this view institutions matter for leaders and entrepreneurs both. Other side, this research has some practical implications i.e. what type of resources have 
compelling effect on job satisfaction and which leadership style is beneficial for organizations. employee's satisfaction.

\section{Review of Literature}

\subsection{Culture}

Culture - a product "group of people" having similar attitudes, behavior and living at the same place. Individuals who belong to a specific culture, contribute identical norms, values, artifacts and history differs from each other. (Gjuraj, 2013). He regards culture as a combined phenomenon that is shaped by the individuals' social environment not their gene (Geeert Hofstede, 1991).

Researchers analyzed that how various cultural characteristics influence entrepreneurship. Similar to these authors, (Sebastian Aparicio, 2018) suggested culture as a predictor of entrepreneurship by using WVS. Countries having social progress orientation supports entrepreneurial activity. Other researches that analyzed these types of results between culture and job satisfaction done by (Pirzada, 2011), (Memon, 2012) and (Pattnaik, 2011). Findings indicate that a culture of organization has a significant impact on job satisfaction of employees.

\subsection{Uncertainty Avoidance}

The term Uncertainty Avoidance refers to the degree to which people seek order, structure, uniformity, formalized procedures and rules that cover their daily life's situations. Practices connected with uncertainty avoidance involved aspects like resistance of taking risk, and to both in changes and development of new products, so, it is projected that society having high uncertainty avoidance allows little support for entrepreneurship (Hayton J. C., 2002).

Previous research concluded the negative relationship between uncertainty avoidance, collectivism and entrepreneurship (Hayton J. C., 2002). In the same way, De Clercq and his colleagues show the negative relation between entrepreneurship and uncertainty avoidance value. (Clercq, 2010) and (Bowen, 2008). So far, relative researchers also found that either there is no relation between cultural uncertainty avoidance and individualism with entrepreneurship (Autio, 2013) or an opposite relation (Hofstede, 2004).

\subsection{In-group Collectivism}

It denotes the loyalty and pride to family, friends and organization of which individual is a member (CASTILLO-PALACIO, 2017). Tiessen remarks that researchers have linked business behavior of the individual with individualist cultures, they found them as founder or individual entrepreneur whereas collectivist societies found more to corporate entrepreneurship (Tiessen, 1997). Reyes and Pinillos in their research mentioned that various studies like (Hunt, 2003), (Baum, 1993) have presented that collectivism and entrepreneurial activity has a positive relation (María-José Pinillos, 2011). Mitchell et al. and Hayton et al. agreed in their opinions, representing that societies where there is a high level of collectivism, a higher level of entrepreneurship expected (Mitchell, 2000) and (James C. HAYTON, 2002). 


\subsection{Leadership}

All over the human history leaders do existed in all cultures. One can learn the philosophy and practice of leaders and leadership from many ancient sources. Recently, several definitions seem to have ideas of setting of goals at their core. Additionally, these are leaders who inspired others and help individuals/ groups and organization to achieve their objectives. (House R. H., 2004) recognized 6 global leadership dimensions. First is team-oriented that highlights effective team building and execution of common goal among them. The second one is participative, replicates the degree to that managers include their colleagues in decision making. Third one is humane dimension reflects considerate and supportive leadership. Fourth is autonomous, it is characterized by an autonomous and independent approach. Fifth dimension is self-protective that emphasizes face-saving and status conscious behaviors and it focuses on security, safety of individuals and groups. Last one is charismatic dimension that reflects the capability of leader to inspire/ to motivate and to expect a high-performance result by holding strongly onto core values of organization (House R. H., 2004).

\subsection{Self-Protective Leadership}

It is a self-centered, competitive and status-conscious leadership style. Self-protective leadership (SPL), which is perceived globally as the least effective of Project GLOBE's six leadership styles, is about ensuring individual and/or group safety and security. It encompasses being self-centered, status-conscious, procedural, conflict-including and face-saving (House R. H., 2004).

It has been seen that entrepreneurship is more flourish is the cultures that accepted self-protective CLT because developing and managing a project need more competitive behavior and emphasizes personal interest. Expanded studies on entrepreneurial motivations presents that entrepreneur firstly seek to complete personal objectives like money/ income, fame and independence by creating a new own business (Birley, 1994; Carter, 2003; Cassar, 2007; Gorgievski, 2011; Kolvereid, 1996; Parker, 2009). (Stephan \& Pathak, 2016) gave so many evidence on entrepreneurship and self-protective leadership relation. Conferring to these researchers, these types of leaders incline to work alone and support minimum risk and uncertainty: these are the attributes that eventually affect entrepreneurial activity.

\subsection{Charismatic Leadership}

The theory of charismatic leadership described by (House.R.J., 1977). According to Klein and House (1995) charismatic leadership need three components: a spark- the leader, igneous material- the flowers and oxygen- an encouraging environment. Yet, by seeing followers as "flammable material" waiting to be exploded by their leaders, these researchers describe flowers as a limited and passive role. This define an outstanding leader as one who is able to inspire, to motivate and able to exert high performance by its followers based on integrity, self-sacrifice and by holding corporate values firmly (Peter Dorfman, 2012). 
(Chen, 2014) found that charismatic CLT have an influence on product innovation and eventually on corporate entrepreneurship. This kind of leader's behavior have a positive impact on a large range of individual and organizational productivity in a variety of contexts, including military (Bass B. A., 2003; Hardy, 2010), business (Barling, 1996; Ensley, 2006; Jung, 2003), public sector (Rafferty, 2004) and education (Koh, 1995). As per the previous research and evidence, it seems that charismatic leadership have a significant impact on entrepreneurial behavior (Stephan \& Pathak, 2016).

\subsection{Entrepreneurship}

It is commonly taken as a new entry in market, i.e. the development of a new project (Gartner, 1989). (Graeme Currie, 2008) describe it as the procedure of identifying and pursuing opportunities. An entrepreneurship may be considered as the process of generating value by taking together all resources and create an opportunity (Drucker, 1985). Entrepreneur is an individual who establishes and manages a business for the principle purpose of growth and profit. The entrepreneur is characterized principally by innovative behavior and will employ strategic management practices in the business (Gartner, 1989).

Individualism and uncertainty avoidance values of culture seen to promote entrepreneurship just like individual entrepreneur ratify these two (Stephan \& Pathak, 2016). Several researches on culture found support for these assumptions (Hayton J. C., 2002). However, a fresh review on this topic identified mixed finding and concluded "that we can be less confident, rather than more, in the existence of a single entrepreneurial culture" (Hayton J. C., 2013).

\subsection{Job Satisfaction}

A function of perception that means individual will get satisfaction when he will get what he expected by his job. (Loke, 1969). A firm's welfare is defined by how its employees perceived about the function and quality of the organization (Warr, 1992). It cannot be happening in isolation as it is a complex phenomenon, but it is depending on some variables such as salary, work condition size and structure of organization, leadership and culture (Boeyens, 1985).

Previous researchers found that superior's support can help individuals to reduce burnout and job stress, ultimately that can increase job satisfaction of those employees. This kind of support can be specifically needed in job tasks where results are not certain, like in environments that demands innovation (Niehoff, 1990; Yuki, 1989). Positive relationships between entrepreneurial intentions and low job satisfaction are well documented in the push theory of entrepreneurship (Brockhaus, 1980; Cromie, 1991; Henley, 2007).

\subsection{Implicit Leadership Theory (ILT)}

The theory was first established by Robert Lord and his colleagues (Nye, 1991). This cognitive theory of leadership is grounded on the idea that personalities produce their own cognitive perceptions and imaginations about the world, and they control their actions and behaviors by practicing these predetermined concepts for the understanding of their 
surroundings (Meindl, 1987; Schyns B. \&., 2004). The theory proposes that members of group hold those inherent anticipations and assumptions related to the qualities, characteristics and traits that are implicit in a leader (Nye, 1991). These expectations named implicit leadership theories, these theories monitor and direct the individual's reactions and insights to leaders (Nye, 1991; Schyns B. \&., 2005). This theory leads the individual's responses and actions appropriately towards the leader by helping them in identifying the leaders to avoid any type of conflict between them. (Schyns B. \&., 2005).

Implicit leadership theory describes that individuals have implicit beliefs, assumptions and convictions regarding characteristics and behaviors that differentiate leader in three ways: effective leaders from ineffective leaders, leaders from followers and moral leaders from evil leaders.

\subsection{Culturally Endorsed Implicit Leadership Theory (CLTs)}

Cultures are different in the views of ideal leadership - in motives, characteristics and behaviors on that they believe as an outstanding leadership trait. These cultural leadership ideals are also referred to as culturally endorsed implicit leadership theories/ CLTs (Dorfman P. H., 2004).

Individuals mostly expect to their superiors to act in line with these ideals and analyze them accordingly. Cultural values show injunctive norms presenting aims of individuals of an organization should be like (Frese, 2015) like culturally endorsed leadership show ideal images of leaders. To date CLT have received a limited attention of researchers, except (Dorfman P. J., 2012) and (House R. D., 2014). They describe that it influences CEO's behavior and when they behave in line with this culture they can perform better and effectively. (Stephan \& Pathak, 2016).

\subsection{Job Demand-Resources Model}

This model was firstly published by (Demerouti, 2001) to understand the background of burnout. of burnout. This model sketched upon (Lee, 1996) a meta-analysis in that thirteen job resources and eight job demand were recognized as much possible reasons of burnout and in the "structural model of burnout" (Maslach, 1996, p. 36). This model proposes that their relation (job demand s and job resources) is crucial for the motivation and development of job strain. More precisely, job resource can safeguard the impact of job demand on job stain and burnout (Bakker A. D., 2003c). There are interdependencies between job demands and job resources. According to (Karasek, 1979), job resources reduce the influence of stress and guard against excessive strain (Arnold B. Bakker \& Demerouti, 2007). It is also postulated - in accordance with the conservation of resources (COR) theory (Hobfoll \& E., 2002) - that the motivation potential of job resources also increases particularly when the job demands are high. 


\subsection{Job Demand}

Demerouti et al. defined job demands as those social, physical and organizational aspects of the job that require sustained mental or physical effort and are therefore associated with certain physiological and psychological costs (Demerouti, 2001, p. 501). Excessive or ill-defined job demands cause a health-impairment process and lead to stress symptoms such as mental or physical exhaustion and, thus, adverse effects on health. (Bakker A. B., 2003, pp. 393-417.)

Although personal resources' moderating impact on the effect of job demands was assumed in earlier studies (Mäkikangas, 2003; Pierce, 2004; Xanthopoulou, 2007) could not confirm this relationship. According to (Huang, 2015), personal resources not only mediate the motivational process but also the health-impairment process. In a similar vein, Hu et al. (2013) reveal a mediation by an equity-based cognitive evaluation process not only between job resources and work engagement but also between job demands and burnout. These findings suggest that personal resources favorably mediate the motivational process between job resources and well-being as well as the health impairment process between job demands and exhaustion within an extended JD-R model (Ralph Kattenbach, 2018). (Molino, 2016) show that job demands can cause workaholism which in turn leads to more intense exhaustion.

\subsection{Job Resource}

Job resources are those physical, social and workplace features that help (a) in the achievement of job-related objectives, (b) in the reduction of job demands and costs associated with them, and (c) in the promotion of personal growth and development. Job resources can cause both an intrinsic and an extrinsic motivational process (Arnold B. Bakker \& Demerouti, 2007).

(Trembath, 2017) focused on the relation of teacher and student as a job resource, intercultural adjustment as a job demand and the link to job satisfaction. They explored for social support teacher and student relation can be a source for the expatriate academics. (Bakker A. B., 2007) postulated - in accordance with the conservation of resources (COR) theory (Hobfoll S. E., 2002 ) - that the motivation potential of job resources also increases particularly when the job demands are high. Individual seeks to obtain and maintain resources including personal characteristics, objects, conditions and energies. Loss of resources (or the threat of loss) induces stress, which in turn leads to anxiety, job dissatisfaction, and thoughts about leaving the job (Ralph Kattenbach, 2018).

\subsection{Social Cognitive Theory (SCT)}

SCT explains the reciprocal relationship between human behavior, cognition and personal factors, and the environment. These three determinants mutually influence each other (Bandura, 1989). SCT, assume a mediating role of personal resources in the relationship between or more precisely: in the perception of environment (working conditions) and positive/negative outcomes (Bandura, Social cognitive theory, 1989). 


\section{Macrothink}

\subsection{Research Framework}

The research examined the relation of independent variables (job demand, job resources, culture values, CLTs and individual entrepreneurship). Figure 1 represents a full model of our research. As mentioned previously, job demands and job resources, the two main job aspects, trigger employee's job satisfaction. Along with these two factors this model illustrates how culture values and CLT affects entrepreneurial intentions and how IE relates to job satisfaction of employees. Therefore, this research model fills the gap of (Stephan \& Pathak, 2016) and (Ralph Kattenbach, 2018) researches by adapting social cognitive theory.

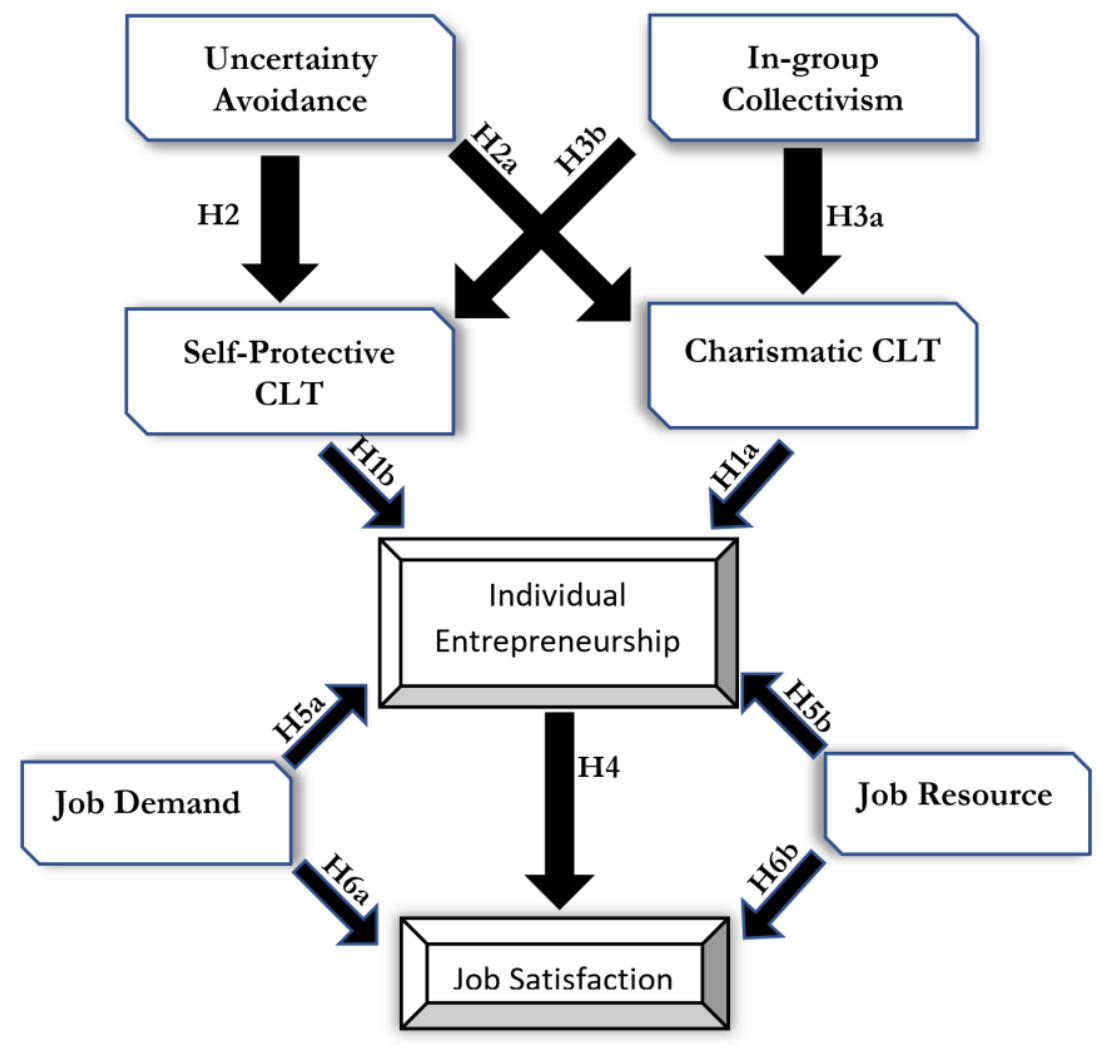

Figure 1. Research Model

\section{Methodology}

\subsection{Sample size}

The sample was selected on the basis of suitability for this study. In this survey, we chose 200 respondents as the sample size by asking them that whether they observe a relationship between dependent and independent variables.

\subsection{Statistical technique}

The data gathered was tested for Hypothesis with the help of Smart pls software used as a Statistical Tool. 


\subsection{Questionnaire Design}

A self-administered questionnaire was developed to collect data and record responses from the target audience. A five-point Likert scale is used in the questionnaire design to classify the responses of the respondents, the scale is ranging from $1=$ strongly agree, $2=$ agree, $3=$ neutral, $4=$ disagree, $5=$ strongly disagree. The items for job demand and job resources were adopted from (Amsterdam, 2019), items for job satisfaction adopted from (DÃ-az Cabrera, 2012), for cultural values, items were adopted from (House R. J., 2004). Items for individual entrepreneurship were adopted from (Bolton D. L., 2019). Items for self-protective and charismatic leadership CLTs adopted from (Alpha, 2006). Survey done by google forms from more than 200 respondents of corporate sector of Karachi, Pakistan.

\section{Data Analysis}

\subsection{Demographics}

Table 1.

\begin{tabular}{|c|c|c|c|}
\hline Variable & Category & Frequency & Percentage \\
\hline \multirow[t]{3}{*}{ Gender } & Male & 134 & 62.3 \\
\hline & Female & 81 & 37.7 \\
\hline & Total & 215 & 100 \\
\hline \multirow[t]{6}{*}{ Age } & $21-25$ years & 90 & 41.9 \\
\hline & 26-30years & 79 & 36.7 \\
\hline & 31-35years & 26 & 12.1 \\
\hline & $35-40$ years & 9 & 4.2 \\
\hline & Above 40 years & 11 & 5.1 \\
\hline & Total & 215 & 100 \\
\hline \multirow[t]{9}{*}{ Organization } & Banking & 23 & 10.7 \\
\hline & Manufacturing & 32 & 14.9 \\
\hline & Telecommunication & 7 & 3.3 \\
\hline & Textile & 5 & 2.3 \\
\hline & Hospitality & 14 & 6.5 \\
\hline & Food & 10 & 4.7 \\
\hline & Software & 18 & 8.4 \\
\hline & Others & 106 & 49.3 \\
\hline & Total & 215 & 100 \\
\hline \multirow[t]{3}{*}{$\begin{array}{l}\text { Employment } \\
\text { Type }\end{array}$} & Part Time & 41 & 19.1 \\
\hline & Full Time & 174 & 80.9 \\
\hline & Total & 215 & 100 \\
\hline $\begin{array}{l}\text { Employment } \\
\text { Level }\end{array}$ & Top Management & 23 & 10.7 \\
\hline
\end{tabular}




\begin{tabular}{lccc} 
& Middle & 106 & 49.3 \\
Management & & \\
Lower & 54 & 25.1 \\
Management & 32 & 14.9 \\
& Non-Management & 215 & 100 \\
\hline Total & 60 & 28 \\
Work Experience & Less than 1 year & 63 & 29.3 \\
& 1-3 years & 45 & 20.9 \\
& 4-6 years & 22 & 10.2 \\
& 7-9 years & 25 & 11.6 \\
& 10 or more & 295 & 100 \\
\hline Total & 3 & 1.4 \\
\hline Mducation & Matriculation & 11 & 5.1 \\
& Intermediate & 77 & 35.8 \\
& Bachelors & 115 & 53.5 \\
& Masters & 9 & 4.2 \\
& MPhil above & 215 & 100 \\
\hline Total & & \\
\hline
\end{tabular}

The demographic information of respondents included gender, age, type of organization worked, employment type, employment level, number of work experience and educational level. Results from frequency distribution suggest that $62.3 \%$ male and $37.7 \%$ female respondents completed this questionnaire in the survey. The percentage age of respondents lying in the bracket of 21-25 years old (41.9\%), 26-30 years old (36.7\%), 31-35 years old $(12.1 \%), 35-40$ years old $(4.2 \%)$, whereas $(5.1 \%)$ of the respondents were of 40 years and above age group. This table shows that $(10.7 \%)$ of respondents were from banking industry, $(14.9 \%)$ were from manufacturing industry, $(3.3 \%)$ were from telecommunication industry, (2.3\%) were from textile industry, $(6.5 \%)$ were form hospitality industry, $(4.7 \%)$ of respondents were from Food industry, $(8.4 \%)$ were from software and mostly $(49.3 \%)$ of respondents were of others category. Ratio of full-time employees $(80.9 \%)$ is higher than part time employees $(19.1 \%)$. While employment level of employees mostly is from middle management $(49.3 \%),(10.7 \%)$ are from top management and $(14.9 \%)$ employees are from non-managerial staff. In this frequency table mostly had 1-3 years of experience comprising (29.3\%), respondents having less than 1 year of experience is $(28 \%),(20.9 \%)$ of respondents had an experience of 4-6 years, $(10.2 \%)$ of respondents had 7-9 years of experience, whereas the respondents having experience of 10 or more years were $(11.6 \%)$. While education of respondents measured in five categories, only (1.4\%) of respondents were from matric group, (5.1\%) respondents were from intermediate category, (35.8\%) were Bachelors, $(53.5 \%)$ were master's and (4.2\%) were MPhil and above. 


\subsection{Descriptive Statistics}

Table 2.

\begin{tabular}{|c|c|c|c|c|c|c|}
\hline \multirow{2}{*}{ Variables } & \multirow{2}{*}{ Question } & \multicolumn{2}{|c|}{$\begin{array}{l}\text { Descriptive } \\
\text { Stats }\end{array}$} & \multicolumn{3}{|c|}{$\begin{array}{l}\text { Confirmatory Factor } \\
\text { Analysis }\end{array}$} \\
\hline & & Mean & St. dev. & $\begin{array}{l}\text { Outer } \\
\text { Loading }\end{array}$ & T Stats & $\begin{array}{l}\mathbf{P} \\
\text { Values }\end{array}$ \\
\hline \multirow[t]{4}{*}{$\begin{array}{l}\text { Charismatic } \\
\text { Leadership }\end{array}$} & $\begin{array}{l}\text { How do diplomatic characteristics of leader } \\
\text { impact on leadership styles? }\end{array}$ & 4.38 & 2.20 & 0.700 & 15.508 & 0.000 \\
\hline & $\begin{array}{l}\text { How do encouraging characteristics of leader } \\
\text { impact on leadership styles? }\end{array}$ & 5.07 & 2.12 & 0.845 & 24.425 & 0.000 \\
\hline & $\begin{array}{l}\text { How do morale booster characteristics of } \\
\text { leader impact on leadership styles? }\end{array}$ & 5.15 & 2.06 & 0.856 & 27.386 & 0.000 \\
\hline & $\begin{array}{l}\text { How do convincing characteristics of leader } \\
\text { impact on leadership styles? }\end{array}$ & 5.23 & 2.06 & 0.848 & 25.717 & 0.000 \\
\hline \multirow{5}{*}{$\begin{array}{l}\text { Self-Protecti } \\
\text { ve } \\
\text { Leadership }\end{array}$} & $\begin{array}{l}\text { How do self-interested characteristics of leader } \\
\text { impact on leadership styles? }\end{array}$ & 3.97 & 1.97 & 0.649 & 10.920 & 0.000 \\
\hline & $\begin{array}{l}\text { How do risk adverse characteristics of leader } \\
\text { impact on leadership styles? }\end{array}$ & 3.98 & 1.88 & 0.600 & 9.115 & 0.000 \\
\hline & $\begin{array}{l}\text { How do egocentric characteristics of leader } \\
\text { impact on leadership styles? }\end{array}$ & 3.65 & 1.87 & 0.537 & 6.914 & 0.000 \\
\hline & $\begin{array}{l}\text { How do cautious characteristics of leader } \\
\text { impact on leadership styles? }\end{array}$ & 4.13 & 1.84 & 0.636 & 9.513 & 0.000 \\
\hline & $\begin{array}{l}\text { How do cunning characteristics of leader } \\
\text { impact on leadership styles? }\end{array}$ & 3.30 & 1.90 & 0.285 & 2.896 & 0.004 \\
\hline \multirow[t]{2}{*}{$\begin{array}{l}\text { In-group } \\
\text { Collectivism }\end{array}$} & $\begin{array}{l}\text { In this organization, group member take pride } \\
\text { in the individual accomplishments of their } \\
\text { group manager. }\end{array}$ & 3.16 & 0.96 & 0.776 & 12.436 & 0.000 \\
\hline & $\begin{array}{l}\text { In this organization, group managers take pride } \\
\text { in the individual accomplishments of group } \\
\text { members. }\end{array}$ & 3.31 & 0.99 & 0.710 & 9.279 & 0.000 \\
\hline \multirow[t]{2}{*}{$\begin{array}{l}\text { Uncertainty } \\
\text { Avoidance }\end{array}$} & $\begin{array}{l}\text { In this organization, orderliness and } \\
\text { consistency are stressed, even at the expense of } \\
\text { experimentation and innovation. }\end{array}$ & 3.10 & 1.03 & 0.628 & 7.986 & 0.000 \\
\hline & $\begin{array}{l}\text { In this organization, organizational } \\
\text { requirements and instructions are clearly } \\
\text { defined. }\end{array}$ & 3.38 & 1.12 & 0.756 & 14.476 & 0.000 \\
\hline \multirow[t]{2}{*}{ Job Demand } & $\begin{array}{l}\text { Do you have felt tensed while you were at work } \\
\text { during the last week. }\end{array}$ & 2.30 & 0.99 & -0.006 & 0.037 & 0.970 \\
\hline & Do you have felt enthusiastic while you were at & 2.92 & 0.95 & -0.202 & 1.245 & 0.214 \\
\hline
\end{tabular}




\begin{tabular}{|c|c|c|c|c|c|c|}
\hline & work during the last week. & & & & & \\
\hline & $\begin{array}{l}\text { Do you have felt optimistic while you were at } \\
\text { work during the last week. }\end{array}$ & 2.96 & 0.87 & 0.654 & 11.536 & 0.000 \\
\hline & $\begin{array}{l}\text { Do you have felt contented while you were at } \\
\text { work during the last week. }\end{array}$ & 2.99 & 0.97 & 0.524 & 7.214 & 0.000 \\
\hline & $\begin{array}{l}\text { Do you have felt depressed while you were at } \\
\text { work during the last week. }\end{array}$ & 2.32 & 0.95 & 0.607 & 8.649 & 0.000 \\
\hline & $\begin{array}{l}\text { Do you have felt calm while you were at work } \\
\text { during the last week. }\end{array}$ & 1.94 & 0.95 & -0.145 & 0.914 & 0.361 \\
\hline & $\begin{array}{l}\text { Do you have felt worried while you were at } \\
\text { work during the last week. }\end{array}$ & 2.02 & 0.93 & -0.018 & 0.121 & 0.903 \\
\hline & $\begin{array}{l}\text { Do you have felt miserable while you were at } \\
\text { work during the last week. }\end{array}$ & 2.96 & 0.95 & -0.059 & 0.374 & 0.709 \\
\hline & $\begin{array}{l}\text { Do you have felt uneasy while you were at } \\
\text { work during the last week. }\end{array}$ & 3.14 & 0.95 & 0.672 & 11.382 & 0.000 \\
\hline & $\begin{array}{l}\text { Do you have felt cheerful while you were at } \\
\text { work during the last week. }\end{array}$ & 2.05 & 1.01 & 0.714 & 13.013 & 0.000 \\
\hline & My work requires continual thoughts. & 3.35 & 1.14 & 0.525 & 4.970 & 0.000 \\
\hline & I have to work with a lot of precision/ accuracy. & 3.60 & 1.13 & 0.716 & 9.423 & 0.000 \\
\hline & I have to give continuous attention to my work. & 3.85 & 1.11 & 0.650 & 7.524 & 0.000 \\
\hline & I have to do things in my work that I dislike. & 2.89 & 1.12 & 0.264 & 1.923 & 0.055 \\
\hline & $\begin{array}{l}\text { I have to do my work in a way which differs } \\
\text { from the method of my choice. }\end{array}$ & 2.86 & 0.98 & 0.378 & 2.696 & 0.007 \\
\hline & $\begin{array}{l}\text { I have conflicts with my supervisor about the } \\
\text { content of my tasks. }\end{array}$ & 2.55 & 1.05 & -0.019 & 0.139 & 0.890 \\
\hline & I have too much work to do. & 3.20 & 1.09 & 0.382 & 3.620 & 0.000 \\
\hline & I have problems with my work pressure. & 2.58 & 1.11 & 0.187 & 1.214 & 0.225 \\
\hline Job resource & $\begin{array}{l}\text { I have freedom in carrying out my work } \\
\text { activities. }\end{array}$ & 3.31 & 1.10 & 0.700 & 19.111 & 0.000 \\
\hline & $\begin{array}{l}\text { I can personally decide how much time I need } \\
\text { for a specific activity. }\end{array}$ & 3.41 & 1.10 & 0.666 & 12.363 & 0.000 \\
\hline & I can organize my work myself. & 3.70 & 1.08 & 0.673 & 12.339 & 0.000 \\
\hline & $\begin{array}{l}\text { I have the opportunity to develop close } \\
\text { friendship in my job. }\end{array}$ & 3.37 & 1.03 & 0.669 & 15.705 & 0.000 \\
\hline & $\begin{array}{l}\text { My supervisor is concerned about the welfare } \\
\text { of the people that work for him/her. }\end{array}$ & 3.16 & 1.08 & 0.642 & 14.613 & 0.000 \\
\hline & People I work with are friendly. & 3.75 & 1.00 & 0.643 & 11.141 & 0.000 \\
\hline & $\begin{array}{l}\text { My job offers me the possibility to progress } \\
\text { financially. }\end{array}$ & 3.28 & 1.15 & 0.665 & 16.677 & 0.000 \\
\hline & $\begin{array}{l}\text { My current job improves my chances and } \\
\text { opportunities in the job market. }\end{array}$ & 3.54 & 1.08 & 0.770 & 24.276 & 0.000 \\
\hline
\end{tabular}




\begin{tabular}{|c|c|c|c|c|c|c|}
\hline & $\begin{array}{l}\text { My job gives me the opportunity to be } \\
\text { promoted. }\end{array}$ & 3.45 & 1.16 & 0.713 & 16.767 & 0.000 \\
\hline & $\begin{array}{l}\text { I receive enough information on the purpose of } \\
\text { my work. }\end{array}$ & 3.59 & 1.00 & 0.725 & 14.435 & 0.000 \\
\hline & $\begin{array}{l}\text { I receive enough information on the results of } \\
\text { my work. }\end{array}$ & 3.58 & 0.95 & 0.782 & 22.445 & 0.000 \\
\hline & $\begin{array}{l}\text { My work provides me with direct feedback on } \\
\text { how well I am doing my work. }\end{array}$ & 3.53 & 1.09 & 0.728 & 16.478 & 0.000 \\
\hline \multirow{4}{*}{$\begin{array}{l}\text { Job } \\
\text { Satisfaction }\end{array}$} & I am very satisfied with the work goals. & 3.46 & 1.06 & 0.888 & 39.897 & 0.000 \\
\hline & $\begin{array}{l}\text { I am very satisfied with the job characteristics, } \\
\text { for example: with the level of autonomy, the } \\
\text { task variety and the creativity. }\end{array}$ & 3.40 & 1.06 & 0.902 & 50.277 & 0.000 \\
\hline & $\begin{array}{l}\text { I am satisfied with your work team, for } \\
\text { example: with the interpersonal relationships, } \\
\text { the co-operation and the participation between } \\
\text { workmates and managers. }\end{array}$ & 3.56 & 1.09 & 0.858 & 36.797 & 0.000 \\
\hline & I am satisfied with the performance criteria. & 3.44 & 1.10 & 0.837 & 22.351 & 0.000 \\
\hline \multirow{9}{*}{$\begin{array}{l}\text { Individual } \\
\text { Entrepreneur } \\
\text { ship }\end{array}$} & I like to take bold actions. & 3.63 & 1.02 & 0.786 & 22.550 & 0.000 \\
\hline & $\begin{array}{l}\text { I am willing to invest a lot of time and/or } \\
\text { money on something that may have high } \\
\text { return. }\end{array}$ & 3.70 & 0.96 & 0.741 & 17.831 & 0.000 \\
\hline & $\begin{array}{l}\text { I tend to act "boldly" in situations where risk is } \\
\text { involved. }\end{array}$ & 3.56 & 0.89 & 0.771 & 19.298 & 0.000 \\
\hline & I often like to try new and unusual activities. & 3.74 & 0.89 & 0.774 & 26.110 & 0.000 \\
\hline & $\begin{array}{l}\text { In general, I prefer to use new/ unique ways in } \\
\text { work instead of revisiting tried ones. }\end{array}$ & 3.83 & 0.91 & 0.784 & 21.952 & 0.000 \\
\hline & $\begin{array}{l}\text { I favour experimentation and original ways to } \\
\text { problem solving. }\end{array}$ & 3.84 & 0.90 & 0.776 & 22.345 & 0.000 \\
\hline & $\begin{array}{l}\text { I usually forecast future problems, needs or } \\
\text { changes. }\end{array}$ & 3.69 & 0.95 & 0.804 & 23.361 & 0.000 \\
\hline & I tend to plan on projects. & 3.70 & 0.97 & 0.750 & 19.276 & 0.000 \\
\hline & $\begin{array}{l}\text { I prefer to 'step-up' and get things going on } \\
\text { projects rather than sit and wait. }\end{array}$ & 3.89 & 0.92 & 0.786 & 18.191 & 0.000 \\
\hline
\end{tabular}

\subsection{Structural equation modeling}

We used SEM to test the hypothesis, test run through the software of Smart PLS. Further to analyze direct and indirect effects of all the variable constructs we done with testing. Moreover, to evaluate the indirect and direct effects of all the constructs the testing was done. To evaluate the structural relationship between endogenous and exogenous, among the different regression model and methods, SEM consider the foremost procedure (Kenny, 1986). Test included in this are multivariate and factor analysis. Further, the regression equation 
targets to describing each construct to analyze the cause and effect relation whereas all factors in the causal model could display their cause and effect results at accurate time. Similarly, the idea to use SEM make sure the application of bootstrapping technique that has been seen a reasonable technique for small and large size of samples and that does not need any type of indirect effects (Hayes, 2013; Bolger, 2002).

\subsection{Measurement of Outer Model}

To study the validity and reliability of instruments is the main object of this model. To measure its reliability and validity, convergent and discriminant validity test performed in Smart PLS software.

\subsection{Composite Reliability}

To measure the stability of questionnaire outcomes we perform Reliability test. The questionnaire will give the same output for the similar target population whenever it is getting reutilized. This demonstrates the inside repeatability and consistency of the survey is high. This also assimilate the legitimacy and dependability of exploration (Hair , 2010).

Composite reliability is used to evaluate the reliability of survey instruments. The normal threshold value is 0.70 and in this research all values of the table are above than 0.70 , and this is an accepted range of reliability. Composite Reliability table is given below:

Table 3.

\begin{tabular}{|l|r|}
\hline Variables & Composite Reliability \\
\hline Charismatic Leadership (CL_) & 0.942 \\
\hline In-group Collectivism (IC) & 0.783 \\
\hline Individual Entrepreneurship (IE) & 0.916 \\
\hline Job Demand (JD) & 0.619 \\
\hline Job Resource (JR) & 0.904 \\
\hline Job Satisfaction (JS) & 0.895 \\
\hline Self-protective Leadership (SPL) & 0.825 \\
\hline Uncertainty Avoidance (UA) & 0.581 \\
\hline
\end{tabular}

\subsection{Factor Loadings Significant}

Table of descriptive statistics also mentioned loadings used in (CFA) confirmatory factor analysis. In the table variables that have a loading value of .5 are considered as strong while constructs with below .5 are better to remove.

\subsection{Convergent Validity}

According to Zeller convergent validity refers to the degree of agreement in two or more measures of identical construct. (Carmines and Zeller, 1979). It was determined by the inspection of variance extracted for each factor. (Fornell, 1981). Discussing to (Fornell, 1981), 
convergent validity is established when the variance extracted value is more than 0.5 and loadings considered as good but they will termed as less effective if the variance extracted values are less than 0.5 . Result displays in the table below:

Table 4.

\begin{tabular}{|c|c|c|c|c|}
\hline & $\begin{array}{l}\text { Cronbach's } \\
\text { Alpha }\end{array}$ & rho_A & $\begin{array}{l}\text { Composite } \\
\text { Reliability }\end{array}$ & $\begin{array}{l}\text { Average Variance } \\
\text { Extracted (AVE) }\end{array}$ \\
\hline Charismatic Leadership (CL) & 0.939 & 0.945 & 0.942 & 0.802 \\
\hline In-group Collectivism (IC) & 0.780 & 0.789 & 0.783 & 0.645 \\
\hline Individual Entrepreneurship (IE) & 0.917 & 0.919 & 0.916 & 0.550 \\
\hline Job Demand (JD) & 0.788 & 0.814 & 0.619 & 0.165 \\
\hline Job Resource (JR) & 0.904 & 0.906 & 0.904 & 0.441 \\
\hline Job Satisfaction (JS) & 0.895 & 0.901 & 0.895 & 0.682 \\
\hline Self-protective Leadership (SPL) & 0.833 & 0.851 & 0.825 & 0.496 \\
\hline Uncertainty Avoidance (UA) & 0.578 & 0.586 & 0.581 & 0.411 \\
\hline
\end{tabular}

\subsection{Discriminant Validity}

Discriminate validity according to (Carmines, 1979) refers to the degree Discriminate validity can be defined as any single construct is dissimilar form other in the model. When AVE loadings are more than 0.5 means that $50 \%$ of variance was took by constructs (Wynne W. Chin, 1998). It is established when elements in diagonal that is the square root of AVE values of each variable, are higher than off-diagonal values in the parallel rows and columns. This test is being conducted to analyze whether unrelated measurement/ ideas are in fact not related. Table is given below to show discriminate validity.

Table 5 .

\begin{tabular}{|l|r|r|r|r|r|r|r|r|}
\hline & \multicolumn{1}{|l|}{ CL_ } & IC & IE & JD & JR & JS & SPL & UA \\
\hline CL_ & 0.895 & & & & & & & \\
\hline IC & 0.398 & 0.803 & & & & & & \\
\hline IE & 0.314 & 0.240 & 0.741 & & & & & \\
\hline JD & 0.446 & 0.419 & 0.651 & 0.407 & & & & \\
\hline JR & 0.435 & 0.471 & 0.599 & 0.760 & 0.664 & & & \\
\hline JS & 0.367 & 0.465 & 0.428 & 0.562 & 0.805 & 0.826 & & \\
\hline SPL & 0.362 & 0.281 & 0.272 & 0.347 & 0.329 & 0.346 & 0.705 & \\
\hline UA & 0.498 & 0.537 & 0.553 & 0.542 & 0.613 & 0.617 & 0.470 & 0.641 \\
\hline
\end{tabular}

4.9 Hetrotrait- Monotrait Ratio HTMT 
Table 6.

\begin{tabular}{|l|r|r|r|l|l|l|l|l|}
\hline & \multicolumn{1}{|l}{$\mathrm{CL}_{-}$} & IC & IE & JD & JR & JS & SPL & UA \\
\hline CL_ & & & & & & & & \\
\hline IC & 0.397 & & & & & & & \\
\hline IE & 0.314 & 0.237 & & & & & & \\
\hline JD & 0.338 & 0.346 & 0.522 & & & & & \\
\hline JR & 0.438 & 0.472 & 0.596 & 0.570 & & & & \\
\hline JS & 0.366 & 0.467 & 0.423 & 0.477 & 0.800 & & & \\
\hline SPL & 0.353 & 0.268 & 0.269 & 0.361 & 0.315 & 0.335 & & \\
\hline UA & 0.499 & 0.531 & 0.562 & 0.467 & 0.606 & 0.609 & 0.462 & \\
\hline
\end{tabular}

According to Hetrotrait-Monotrait criteria that all the values should be less than .9. In actual when there are multiple constructs in real research situation, the HTMT interference analysis involves the multiple testing problem. Above table showed that all the values are less than 0.9 that observed the third criteria of discriminant validity of measuring has been also proved among all the discussed variables of the study.

\subsection{Model Fit Measures}

This model's fitness in Smart PLS can be defined by several measures like standardized root mean square residual (SRMR) and Normed Fit Index (NFI), Exact model fits such as d_ULS and d_G and $\chi^{2}$ (Chi-square). It measures the consisting the measured value of both estimated as well as saturated model as reported in the table. It basically analyzes the correlation between the constructs, it takes model structure into as the fitness of the model in SEM-PLS is defined by various measures such as standardized root-mean-square residual (SRMR), and the exact model fits like d_ULS and d_G, Normed Fit Index (NFI), and $\chi^{2}$ (Chi-square). The model fit measures consisting the measured value of both saturated model as well as the estimated model is reported in above Table. The saturated model assesses the correlation between all constructs. The estimated model, on the other hand, takes model structure into interpretation and based on total effects scheme.

Table 7.

\begin{tabular}{|c|c|c|}
\hline & Saturated Model & Estimated Model \\
\hline SRMR & 0.101 & 0.109 \\
\hline d_ULS & 16.400 & 19.077 \\
\hline d_G & 4.107 & 4.150 \\
\hline Chi-Square & $4,173.173$ & $4,195.278$ \\
\hline NFI & 0.503 & 0.500 \\
\hline
\end{tabular}

\section{Hypothesis Testing}

Bootstrapping is one of the key steps in Smart PLS, that gives the data of consistency. In this 


\section{I Macrothink}

process sub-tests are drawn from the very first example including substitution. (Hair, Matthews, Matthews, \& Sarstedt, 2017). It provides the information of stability of coefficient estimate. In this procedure, many sub-samples are drawn from the original sample with replacement. (Hair, Matthews, Matthews, \& Sarstedt, 2017). When we run bootstrap routine, PLS displayed the t-values for SEM. Following table shows the path coefficient results for all the hypothesis. When $(\mathrm{p}<.005)$ at $\alpha=0.05$ this shows the relationship is significant. Basically, path showing whether the relation between measured and latent variables are significant or not. It is representing in the diagram below.

$\mathrm{R}$ square of 0.448 that suggests the variation caused in self-protective leadership, due to uncertainty avoidance is $44.8 \%$, and $4.1 \%$ due to in-group collectivism. Variation caused in Charismatic Leadership due to uncertainty avoidance is $4.1 \%$ and due to in group collectivism is $18.3 \%$. Furthermore, it is shown that variation triggered in Individual Entrepreneurship due to Self-protective leadership is $0.036,-0.008$ due to charismatic leadership, $45.8 \%$ due to job demand and $24.4 \%$ due to job resource. Value also shows the impact of independent variables on job satisfaction as $90.9 \%$ of job resource but job demand and individual entrepreneurship are -0.091 and -0.058 respectively that shows both has negative impact on job satisfaction.

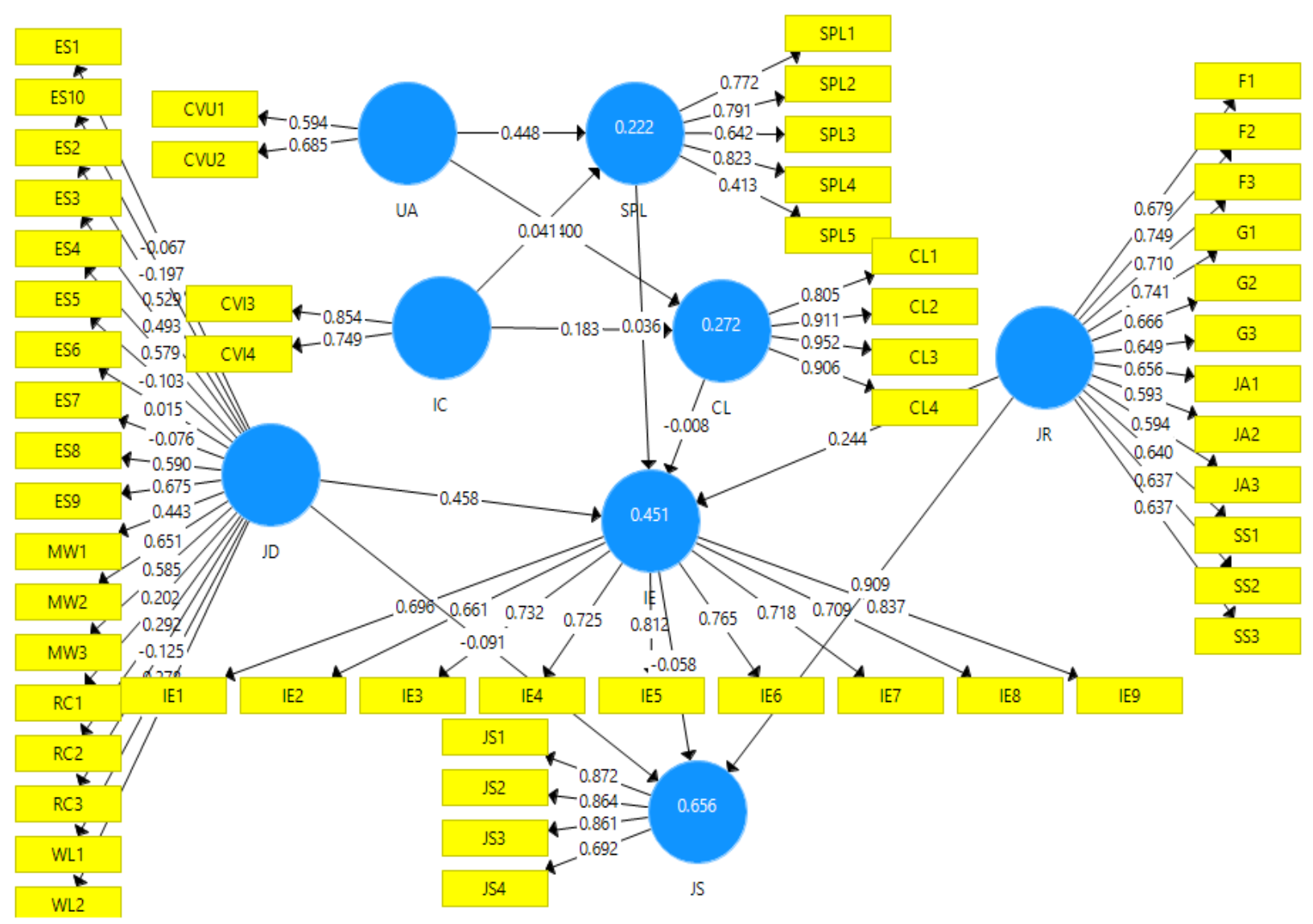


Table 8.

\begin{tabular}{|c|c|c|c|c|c|}
\hline Hypothesis & & $\begin{array}{l}\text { Original } \\
\text { Sample } \\
\text { (O) }\end{array}$ & $\begin{array}{l}\text { T Statistics } \\
(|\mathrm{O} / \mathrm{STDEV}|)\end{array}$ & P Values & Conclusion \\
\hline Hyp 1a & $\begin{array}{l}\text { Charismatic Leadership -> Individual } \\
\text { Entrepreneurship }\end{array}$ & 0.022 & 0.355 & 0.723 & $\begin{array}{l}\text { Not } \\
\text { Supported }\end{array}$ \\
\hline Hyp 1b & $\begin{array}{l}\text { Self-Protective Leadership -> Individual } \\
\text { Entrepreneurship }\end{array}$ & 0.047 & 0.8 & 0.424 & $\begin{array}{l}\text { Not } \\
\text { Supported }\end{array}$ \\
\hline Hyp 2a & $\begin{array}{l}\text { Uncertainty Avoidance -> Charismatic } \\
\text { Leadership }\end{array}$ & 0.283 & 3.779 & 0.000 & Supported \\
\hline Hyp 2b & $\begin{array}{l}\text { Uncertainty Avoidance } \quad \text {-> } \\
\text { Self-Protective Leadership }\end{array}$ & 0.285 & 3.814 & 0.000 & Supported \\
\hline Hyp 3a & $\begin{array}{l}\text { In-group Collectivism -> Charismatic } \\
\text { Leadership }\end{array}$ & 0.241 & 3.1 & 0.002 & Supported \\
\hline Hyp 3b & $\begin{array}{l}\text { In-group Collectivism -> Self-Protective } \\
\text { Leadership }\end{array}$ & 0.126 & 1.757 & 0.08 & Supported \\
\hline Hyp 4 & $\begin{array}{l}\text { Individual Entrepreneurship } \quad->\text { Job } \\
\text { Satisfaction }\end{array}$ & -0.018 & 0.238 & 0.812 & $\begin{array}{l}\text { Not } \\
\text { Supported }\end{array}$ \\
\hline Hyp 5a & $\begin{array}{lrll}\text { Job } & \text { Demand } & -> & \text { Individual } \\
\text { Entrepreneurship } & & \\
\end{array}$ & 0.346 & 3.485 & 0.001 & Supported \\
\hline Hyp 5b & $\begin{array}{llll}\text { Job Resource } \quad-> & \text { Individual } \\
\text { Entrepreneurship } & & \\
\end{array}$ & 0.298 & 3.215 & 0.001 & Supported \\
\hline Нур 6а & Job Demand -> Job Satisfaction & 0.018 & 0.201 & 0.841 & $\begin{array}{l}\text { Not } \\
\text { Supported }\end{array}$ \\
\hline Hyp 6b & Job Resource -> Job Satisfaction & 0.726 & 8.862 & 0.000 & Supported \\
\hline
\end{tabular}

Results indicated both form of leadership both charismatic and self-protective, have insignificant effect on employee's job satisfaction. However, both cultural components like collectivism and uncertainty avoidance have a significant positive effect on both form of leaderships. Moreover, job demand and job resource significantly affect entrepreneurship, however, entrepreneurship doesn't lead to job satisfaction. Hence, entrepreneurship doesn't seem to mediate the job demand, resource and satisfaction nexus. However, job resource directly and significantly affects JS, unlike job demand. Similarly, leadership doesn't play a mediatory role between culture and entrepreneurship. This imply that the link from culture to leadership to entrepreneurship and lastly to job satisfaction cannot be established.

\section{Discussions}

Results of this study indicate relationships among style of a leadership, social cognition factors including job demand and resources, job satisfaction and entrepreneurial intentions of employees. To check the relationship structure model was made and tested in support of hypothesis, we do not found support for hypotheses $1 \mathrm{a}$ and $1 \mathrm{~b}$ i.e. charismatic leadership and 
self-protective leadership have significant impact on individual entrepreneurship of employees. This finding is although not consistent with the finding of past studies (Stephan \& Pathak, 2016) as it shown there is no relation between these two. For hypothesis $2 a$ and $2 b$ we found the support that the effects of uncertainty avoidance on both CLTs is significant. Such findings align with the previous research that those cultures who value more to uncertainty avoidance are more likely to respect self-protective leadership (Robert J. House, 2014), so far charismatic CLT can also present uncertainty by initiating a change process (Dorfman P. H., 2004).

Our findings supporting hypothesis $3 \mathrm{a}$, that culture in-group collectivism value is positively related with charismatic leadership, charismatic CLT, assumed that leader is a source as an agent, empirical research supports this association. On the other hand, cultures that value individualism are more with self-protective leadership. Finding of our study does not support the hypothesis $3 \mathrm{~b}$ i.e. culture in-group collectivism value is positively related with self-protective CLT. The reason is that self-protective leadership stresses a self-focused behavior of leader that aligns with the emphasis on the individual over group's concerns, it also has characteristics which are consistent with collectivism like face saving (Dorfman P. H., 2004). It is found from the results of hypothesis 4 that individual entrepreneurship (IE) has no significant impact on job satisfaction, it contradicts previous research that when individuals experience low level of job satisfaction, they intent to start their own new business (Lena Lee, 2011). According to our finding job demand and job resources that are main factors of social cognition theory have a direct significant effect on entrepreneurial intentions of employees $5 \mathrm{a}$ and 5b, these hypothesis is in support with COR theory (Hobfoll S. E., 2002) and (Bandura, Self-efficacy: The exercise of control, 1997) triadic reciprocal determinism in that the individuals shape their perception of the work environment through their individual entrepreneurship orientation and, in turn, their entrepreneurial orientation is influenced by the demands and resources of the work environment. Furthermore, results found that job demand has negative impact on level of job satisfaction of employees i.e. hypothesis $6 a$, on the contrary, hypothesis $6 \mathrm{~b}$ validates the study of (Ralph Kattenbach, 2018) that indicates the cognitive workload acts like a genuine job resource; it has a positive impact on job satisfaction.

\section{Conclusion}

In this study we conclude with the findings that an entrepreneurial oriented employee seeking autonomy, growth potential, optimization, competition, proper feedback and proactiveness - perceives his/ her working environment in a more positive light, leading to high individual entrepreneurship ability as well as increased job satisfaction. Further, it can not only influence, but also forecasted by individual's viewpoints of its organizational culture, specifically due to social support and leadership (Dimitrios Belias, 2014). Therefore, we integrate insights from leadership theory and propose a fresh prospective of Culturally endorse implicit leadership theories to advance this research.

In summary, this study has determined that job resource factors have significantly effect on job satisfaction and entrepreneurial intentions of the employees. Therefore, it is essential that programs aimed at improving the overall quality of the work environment in organizations 
should focus on the cultural values shared by workers and employers, employee's involvement of effective EO for increasing retention behaviors. These changes will lead to maintain and improve level of job satisfaction of their employees.

However, we did not find any significant and consistent effects of both CLTs i.e. Charismatic and Self-protective on individual entrepreneurship of employees. However, we find that culture values have a significant influence on the style of leadership in any organization. The findings also indicate that there is no impact of Individual entrepreneurship on job satisfaction. It is concluded that for job satisfaction role conflict, cognitive workload and emotional strain must be avoided and managed. Employees must get decision latitude, managerial ability and social support to be satisfied with their roles. The study pays attention to a better understanding of the system through which culture values, leadership styles, job demand, job resource and individual entrepreneurship ability of employee influenced their job satisfaction.

Owing to the obvious influence of working conditions i.e. job demand and resource on job satisfaction, it is important for organizations to (continue to) organize work in such a way that a demands-overload is avoided, and resources are developed. These findings suggest that job resources - or at least an increased task autonomy and cognitive workload - play a significant role in the lowering of exhaustion through the facilitation of employees' entrepreneurial thinking that leads to job satisfaction.

Previous studies have emphasized job resource's role as a preventor of exhaustion. Within our study this link is supported for the job resources decision latitude and social support as well as for the challenging job demand cognitive workload. Perhaps cognitive workload in the workplace is seen as a challenge with an opportunity for personal growth and development. Based on a meta-analysis, (Crawford, 2010) state that there are two types of demands, challenges and hindrances. The latter refers to job demands as proposed by the JD-R model with a fostering effect on burnout and a negative effect on job satisfaction. Our findings also highlight some practical implications. Due to the wide-ranging digitalization of job tasks in all industries and the broad adoption of IT work organization in other industries (e.g. agile organization), we can assume that the practical impact of our findings applies to modern job profiles in agile organizations in general. Companies undergoing reorganization to become more agile should consider the interplay between job conditions and work orientations.

This research will help to comprehend previous research findings on culture values and entrepreneurship. This also eclipses the debate that either individualism supports entrepreneurship or collectivism. Researcher validate that CLT is a channel through which uncertainty avoidance and collectivism frame entrepreneurship in any organization. It makes difficult this research by emphasizing various aspects of culture have different effects on entrepreneurship and that these effects stream by different mechanisms. Researcher also deliberate which factors lead to job satisfaction of employee? how culture, job related factors and individual entrepreneurship can influence the level of job satisfaction in employees of Karachi. 


\section{Limitations}

This analysis was conducted at a small level i.e. only from the employees of Karachi, Pakistan, so future research might motivate an integrative multilevel analysis filled this gap by analyzing a wide sample of individuals and countries, which allowed them to apply a multilevel approach. Because of lack of resource such as budget and time, the survey was conducted by google forms. This sample may not be revealing the viewpoints that prevails in many other countries. In addition, it might be interesting to extend the list of items or ask about other types of leaders. For example, a contrast of implicit theories of female versus male leaders/ business versus political leaders can be of high interest to further discover preferred leadership trait across cultures.

\section{References}

Agho, A. M. (1993). Determinants of employee job satisfaction: An empirical test of a causal model. Human Relations, 1007-1027.

Alpha, G. P. (2006). Global Leadership and Organizational Behavior Effectiveness Project. The GLOBE Foundation.

Amsterdam, A. (2019). QEEW2.0 - Questionnaire for the Experience and Evaluation of Work.

Andreas Engelen, T. C. (2013). The Effect of Organizational Culture onEntrepreneurial Orientation: A Comparison betweenGermany and Thailand. Journal of Small Business Management.

Arnold B. Bakker, E. D., \& Demerouti, E. (2007). The Job Demands-Resources model: state of the art. Emerald Group Publishing Limited.

Autio, E. P. (2013). Consequences of cultural practices for entrepreneurial behaviors. J. Int. Bus. Stud, 334-362.

Aycan, Z. K. (2000). Impact of culture on human resource management practices: A ten-country comparison. Applied Psychology An International Review, 49, 192-220.

Baker, D. a. (1982). Psychological Management of Individual Performance. Wiley.

Bakker, A. B. (2003). Dual processes at work in a call centre: An application of the job demands - resources model. European Journal of Work and Organizational Psychology.

Bakker, A. B. (2007). The job demands-resources model: State of the art. Journal of Managerial Psychology, 309-328.

Bakker, A. D. (2003c). A multi-group analysis of the Job Demands-Resources model in four home care organizations. International Journal of Stress Management.

Bandura, A. (1986). Social Foundation of Thought and Action: A Social Cognitive Theory. Prentice-Hall, Englewood Cliffs. 


\section{Macrothink

Bandura, A. (1989). Social cognitive theory. Annals of child development, 1-60.

Bandura, A. (1997). Self-efficacy: The exercise of control. New York: NY: Freeman.

Barling, J. W. (1996). Effects of transformational leadership training on attitudinal and financial outcomes: a field experiment. Journal of Applied Psychology, 827-832.

Bass, B. A. (2003). Predicting unit performance by assessing transformational and transactional leadership. Journal of Applied Psychology, 207-218.

Bass, B. a. (2008). The Bass Handbook of Leadership: Theory, Research, and Managerial Applications. New York: The Free Press.

Baum, J. R. (1993). Nationality and work role interactions: A cultural contrast of Israeli and US entrepreneurs'versus managers' needs. Journal of Business Venturing.

Beyard, N. (1997). Unternehmens- und personalpolitische Relevanz der Arbeitszufriedenheit. Bern: Verlag Paul Haupt.

Bickerton, B. G.-B. (2014). Spiritual resources in the job demands-resources model. Journal of Management. Spirituality and Religion, 245-268.

Bird Barbara. (1988). Implementing Entrepreneurial Ideas: The Case of Intention. Academy of Management Review.

Birley, S. W. (1994). A taxonomy of business start-up reasons and their impact on firm growth and size. J. Bus. Ventur, 7-31.

Biswas, S. (2009). Organization culture and transformational leadership as predictors of employee performance (Vols. Vol. 44, No. 4, ). The Indian Journal of industrial Relations,.

Boeyens, M. (1985). The synergistic nature of organizational climate, Unpublished doctoral thesis.

Bolger, P. E. (2002). Mediation in Experimental and Nonexperimental Studies: New Procedures and Recommendations. Psychological Methods, 422-445.

Bolton, D. L. (2012). Individual entrepreneurial orientation: Development of a measurement instrument. Education Training, 219-233.

Bolton, D. L. (2019). Individual entrepreneurial orientation: development of a measurement instrument. Individual entrepreneurial orientation.

Bowen, H. D. ( 2008). Institutional context and the allocation of entrepreneurial effort. J. Int. Bus. Stud, 747-767.

Brenda L. Mak, H. S. (1999). A con®rmatory factor analysis of IS employeemotivation and retention. Information \& Management, 265-276. 
Brenninkmeijer, V. D. (2010). Regulatory focus at work: The moderating role of regulatory focus in the job demands-resources model. Career Development International, 708-728.

Brockhaus, R. (1980). The effect of job dissatisfaction on the decision to start a business. Journal of Small Business Management, 37-43.

Carmines, E. G. (1979). Reliability and Validity Assessment. Thousand Oaks.

Carter, N. G. (2003). The career reasons of nascent entrepreneurs. J. Bus. Ventur, 13-39.

Cassar, G. (2007). Money, money, money? A longitudinal investigation of entrepreneur career reasons, growth preferences and achieved growth. Entrep., 89-107.

Castillo-Palacio, M. B. C. C. (2017). The Relationship between Culture and Entreprenurship: From Cultural Dimensions of Globe Project (Vol. Vol. 38 ( $\mathrm{N}^{\mathrm{o}}$ 34) Año 2017. Pág. 12). Revista Espacios.

Caza, A. (2009). Positive Organizational Scholarship: What does it Achieve? . In The SAGE Handbook of Organizational Behavior, 99-116.

Chao, G. A. K. (1994). Organizational socialization: Its content and consequences. Journal of Applied Psychology, 730-743.

Chen, Y. T. ( 2014). CEOs' transformational leadership and product innovation performance: the roles of corporate entrepreneurship and technology orientation. Journal of Product Innovation Management, 2-17.

Cherchem, N. (2017). The relationship between organizational culture and entrepreneurial orientation in family firms: Does generational involvement matter? Journal of Family Business Strategy.

Cherchem, N. (2017). The relationship between organizational culture and entrepreneurial orientation in family firms: Does generational involvement matter? Jounal of Family Business Strategy.

Claudia Felix, S. A. (2018). Leadership as a driver of entrepreneurship: an international exploratory study. Journal of Small Business and Enterprise Development.

Clercq, D. D. (2010). Themoderating effect of institutional context on the relationship between associational activity and newbusiness activity inemerging economies. Int. Bus, 85-101.

Cogliser, C. A. (2004). The intersection of leadership and entrepreneurship: mutual essons to be learned". Leadership Quarterly, 771-799.

Corbin, L. (1977). Productivity and job satisfaction in research and development: Associated individual and supervisory variables. Airforce Institute of Technology. 


\section{Macrothink

Crawford, E. R. (2010). Linking job demands and resources to employee engagement and burnout: A theoretical extension and meta-analytic test. Journal of Applied Psychology, 834-848.

Cromie, S. (1991). Business ownership as a means of overcoming job dissatisfaction. Personnel Review, 19-24.

DÃ-az Cabrera, D. H.-F. (2012). Organisational Practices Questionnaire. Measurement Instrument Database for the Social Science.

Dana, L. (1995). Entrepreneurship in a remote sub-Arctic community: Nome, Alaska. Entrepreneurship Theory and Practice, 57-73.

DB, B. (1985). The study of stress at work. Annu Rev Public Health.

Deanne N Den Hartog, R. J.-Q. (1999). Culture specific and cross-culturally generalizable implicit leadership theories: are attributes of charismatic/transformational leadership universally endorsed? The Leadership Quarterly, 19-256.

DeBoer, C. (1978). The polls: Attitudes toward work. Public Opinion Quarterly, 565-581.

Demerouti, E. B. (2001). The job demandsresources model of burnout. Journal of Applied Psychology.

Dimitrios Belias, A. K. (2014). Organizational Culture and Job Satisfaction: A Review. International Review of Management and Marketing, 132-149.

Dorfman, P. H. (2004). Leadership and cultural variation. Culture Leadership and Organizations the GLOBE Study of 62 Societies. Sage, Thousand Oaks, CA,.

Dorfman, P. J. (2012). GLOBE: a twenty year journey into the intriguing world of culture and leadership. . J.World Bus., 504-518.

Drucker, P. F. (1985). Entrepreneurship and innovation: Practice and principles. NY: Harper Business.

Elenkov, D. a. (2005). Top management leadership and influence on innovation: the role of sociocultural context. Journal of Management, 381-402.

Ensley, M. P. (2006). The moderating effect of environmental dynamism on the relationship between entrepreneur leadership behavior and new venture performance. Journal of Business Venturing, 243-263.

Ensley, M. P. (2006). The moderating effect of environmental dynamism on the relationship between entrepreneur leadership behavior and new venture performance. Journal of Business Venturing, 243-263.

Fornell, C. A. (1981). Evaluating Structural Equation Models with Unobservable Variables and Measurement Error. Journal of Marketing Research, 39-50. 
Frese, M. (2015). Cultural practices, norms, and values. Journal of Cross-Cultural Psychology, 1327-1330.

Furnham, A. A. (1990). Consequences of person-environment incongruence: absenteeism, frustration, and stress. The Journal of Social Psychology , 187-204.

Gartner, W. B. (1989). "Who is an Entrepreneur?" Is the wrong question. Entrepreneurship Theory and Practice, 47-68.

Geeert Hofstede, G. J. (1991). Cultures and Organizations: Software of the Mind. Natherland: ISBN 0-07-143959-5.

GEORGE Gerard, S. A. (2002). Culture and its Consequences for Entrepreneurship. Entrepreneurship Theory and Practice, 5-8.

George, G. (2002). Culture and its consequences for entrepreneurship. Entrepreneurship Theory and. Practice.

Gjuraj, E. (2013). The Importance of National Culture Studies in the Organizational Context. European Scientific Journal (ESJ).

Gomes, F. C. ( 2000). Manajemen Sumber Daya Manusia, Andi Offset, Yogyakarta. .

Gorgievski, M. A. ( 2011). Small business owners' success criteria, a values approach to personal differences. J. Small Bus. Manag., 207-232.

Graeme Currie, M. H. (2008). Entrepreneurial Leadership in the English Public Sector: Paradox or Possibility? Public Administration, 987-1008 .

Grant, A. C. (2007). Happiness, Health, or Relationships? Managerial Practices and Employee Well-Being Tradeoffs. Academy of management perspectives, 51-63.

Guglielmi, D. S. (2012). Self-efficacy and workaholism as initiators of the job demands-resources model. Career Development International, 375-389.

Gupta, V. M. (2004). Entrepreneurial leadership: developing and measuring a cross-cultural construct. Journal of Business Venturing, 241-260.

Hair, J. F., Matthews, L. M., Matthews, R. M., \& Sarstedt, M. (2017). PLS-SEM or CB-SEM: updated guidelines on which method to use. Int. J. Multivariate Data Analysis, 107-123.

Hardy, L. C. (2010). The relationship between transformational leadership behaviors, psychological, and training outcomes in elite military recruits. Leadership Quarterly, 20-32.

Harrison, P. A. (2018). Islamic insights on entrepreneurial leadership in Harrison, R.T. and Leitch, C.M. (Eds),. Research Handbook on Entrepreneurship and Leadership, Edward Elgar,.

Harrison, R. L. (2015). Breaking glass: toward a gendered analysis of entrepreneurial leadership. Journal of Small Business Management, 693-713. 
Hayes, A. F. (2013). Introduction to Mediation, Moderation, and Conditional Process Analysis. Guilford Press.

Hayton, J. C. (2002). National culture and entrepreneurship: A review of behavioral research. Entrepreneurship Theory and Practice.

Hayton, J. C. (2013). Is there an entrepreneurial culture? A review of empirical research. $708-731$.

Henley, A. (2007). Entrepreneurial aspiration and transition into self-employment: Evidence from British longitudinal data. Entrepreneurship and Regional Development, 253-280.

Hisrich, R. \&. (1986). Characteristics of the minority entrepreneur Business Management. Journal of Small, 1-8.

Hobfoll, E. S. (2002). Social and psychological resources and adaptation. Review of General Psychology.

Hobfoll, S. E. (2002). Social and psychological resources and adaptation. Review of General Psychology, 307-324.

Hofstede, G. N. (2004). Culture's role in entrepreneurship. In: Ulijn, J., Brown, T. Innovation, Entrepreneurship.

Hornsby, J. K. (2002). Middle managers' perception of the internal environment for corporate entrepreneurship: assessing a measurement scale. Journal of Business Venturing, 253-273.

House, R. D. (2014). Strategic Leadership Across Cultures: GLOBE Study of CEO Leadership Behavior and Effectiveness in 24 countries. Sage.

House, R. H. (2004). Culture, Leadership and Organizations: The Globe Study of 62 Societies (Review). Journal of Applied Christian Leadership.

House, R. H. (2006). Culture, Leadership, and Organizations: The GLOBE Study of 62 Societies [review] . Journal of Applied Christian Leadership, 55-71.

House, R. J. (2004). Culture, Leadership, and Organizations: The GLOBE Study of 62 Societies.

House.R.J. (1977). A 1976 Theory of Charismatic Leadership. The cutting edge.

Huang, J. W. (2015). The Job Demands-Resources Model and Job Burnout: The Mediating Role of Personal Resources. Current Psychology, 562-569.

Hunt, S. L. (2003). Culture as a predictor of entrepreneurial activity. Frontiers of entrepreneurship research.

Hur, W.-M. R.-Y.-H. (2016). Positive psychological capital and emotional labor in Korea: The job demands-resources approach. International Journal of Human Resource Management, 477-500. 


\section{Macrothink

Ilham, R. ( 2018). The Impact of Organizational Culture and Leadership Style On Job Satisfaction and Employee Performance. Journal of Advanced Management Science, 6(1).

James C., \& Hayton, G. G. (2002). National Culture and Entrepreneurship: A Review of Behavioral Research. Entrepreneurship Theory and Practice, 26, (4),.

Judge, T. A. (2001). Relationship of core self-evaluations traits - self-esteem,generalized self-efficacy, locus of control, and emotional stability - with job satisfactionand job performance: A meta-analysis. Journal of Applied Psychology, 80-92.

Jung, D. C. (2003). The role of transformational leadership in enhancing organizational innovation: hypotheses and some preliminary findings. Leadership Quarterly, 525-544.

Kang, J. S. (2015). CEOs' leadership styles and managers' innovative behaviour: investigation of intervening effects in an entrepreneurial context. Journal of Management Studies, 532-554.

Karasek, R. A. (1979). Job demands, job decision latitude, and mental strain: Implications for job redesign. Administrative Science Quarterly.

Karatepe, O. M. (2015). Do personal resources mediate the effect of perceived organizational support on emotional exhaustion and job outcomes? International Journal of Contemporary Hospitality Management, 4-26.

Kenny, R. M. (1986). The Moderator-Mediator Variable Distinction in Social Psychological Research: Conceptual, Strategic, and Statistical Considerations. Journal of Pe nality and Social Psychology, 1173-1182 .

Kluckhohn, C. (1951). The study of culture. Stanford University Press.

Koh, W. S. (1995). The effects of transformational leadership on teacher attitudes and student performance in Singapore. Journal of Organizational Behavior, 319-333.

Kolvereid, L. (1996). Organizational employment versus self-employment: reasons for career choice intentions. Entrep. Theory Pract., 23-31.

Konstantinos M. Karyotakis, V. S. (2016). Organizational Factors, Organizational Culture,Job Satisfaction And Entrepreneurial Orientation In Public Administration. The european journal of applied economics.

Krueger, N. R. (2000). Competing models of entrepreneurial intentions. Journal of Business Venturing , 411-432.

L., H. J. (1985). Making Vocational Choices: A Theory of Vocational Personalities and Work Environment. (Prentice Hall, Englewood Cliffs, NJ).

Lee, R. T. (1996). A meta-analytic examination of the correlates of the three dimensions of job burnout. Journal of Applied Psychology. 
Leitch, C. a. (2017). Entrepreneurial leadership: insights and directions. International Small Business Journal, 147-156.

Leitch, C. a. (2018). Entrepreneurial leadership: a critical review and research agenda. London: SAGE Publications.

Lena Lee, P. K. (2011). Entrepreneurial intentions: The influence of organizational and individual factors. Journal of Business Venturing, 124-136.

Liu, H. (2015). The role of work-family role integration in a job demands resources model among Chinese secondary school teacher. Asian Journal of Social Psychology, 288-298.

Lo Presti, A. (2014). Testing the job demands-resources model: Evidence from a sample of italian employees. TPM - Testing, Psychometrics Methodology inPsychology, 89-101.

Loke, E. (1969). What is Job Satisfaction? Organizational Behaviour and Human Performance .

Lyons, T. A. (2012). Entrepreneurship and community: the next frontier of entrepreneurship inquiry. Entrepreneurship Research Journal, 1-26.

M., K. M., \& N, A. (2006). The Impact of Leadership and Change Management Strategy on Organizational Culture and Individual Acceptance of Change during a Merger (Vols. Vol.17, No.S1). British Journal of Management.

MacIntosh, N. A. (1990). Structuration theory in management accounting. Accounting Organizations and Society, 455-477.

Mäkikangas, A. (2003). Psychosocial work stressors and well-being: self esteemand and optimism as moderators in a one-year longitudinal sample. Personality and Individual Differences, 537-557.

María-José Pinillos, L. R. (2011). Relationship between individualist-collectivist culture and entrepreneurial activity: evidence from Global Entrepreneurship Monitor data. Small Business Economics.

Marijana Matijaš, M. M. (2018). Job resources and satisfactionacross gender: the role ofacross gender: the role ofwork-family conflict. Journal of Managerial Psychology.

Maslach, C. J. (1996). Maslach burnout inventory 3rd ed. Consulting Psychologists Press.

Meindl, J. (1987). The romance of leadership and the evaluation of organizational performance. Academy of Management Journal, 91-109.

Memon, M. S. (2012). The Impact of Organizational Culture on the Employees' Job Satisfaction \& Organizational Commitment: A Study of Faculty Members of Private Sector Universities of Pakistan. Interdisciplinary. Journal Of Contemporary Research In Business. 
Mitchell, R. K. (2000). Cross-cultural cognitions and the venture creation decision. Academy of Management Journal.

Molino, M. B. (2016). The role of workaholism in the job demands-resources model. Anxiety, Stress, and Coping, 400-414.

Neupert, C. C. (2003). Culture and National Conditions Facilitating Entrepreneurial Start-ups. Journal of International Entrepreneurship, 313-330.

Niehoff, B. E. (1990). The impact of top-management actions on employee attitudes and perceptions. Group and Organization Studies., 337-352.

Norbom, H. A. (2016). Leadership and innovation: informal power and its relationship toinnovative culture. Journal of Leadership Studies, 18-31.

Nye, J. L. (1991). The effects of prototype-based biases on leadership appraisals: A test of leadership categorization theory. Small Group Research, 360-375.

Parker, S. (2009). The Economics of Entrepreneurship. Cambridge University Press.

Pattnaik, K. S. (2011). Linkage Between Oraganizational Culture and Job satisfaction. International Journal of Multidiscriplinary Management Studies.

Peter Dorfman, M. J. (2012). GLOBE: A twenty year journey into the intriguing world of culture and leadership. Journal of World Business.

Pierce, J. L. (2004). Self-esteem within the work and organizational context: A review of the organization-based self-esteem literature. Journal of Management, 591-622.

Pinillos M.J, R. L. (2011). Relationship between individualist-collectivist culture and entrepreneurial activity: evidence from Global Entrepreneurship Monitor data. Small Business.

Pirzada, S. U. (2011). Organizational Culture and Its Impact on the Job Satisfaction of the University Teachers of Lahore. International Journal of Business and Social Science.

Quiñones, M. V. (2013). Do job resources affect work engagement via psychological empowerment? A mediation analysis. Revista de Psicologia Del Trabajo Y de Las Organizaciones, 127-134.

Rafferty, A. A. (2004). Dimensions of transformational leadership: conceptual and empirical extensions. Leadership Quarterly, 329-354.

Ralph Kattenbach, S. F. (2018). Entrepreneurial orientation and the job demands-resources model. Emrald Insight.

Robert G. Lord, K. J. (1991). Leadership and Information Processing: Linking Perception and Performance. 
Robert J. House, P. W. (2014). Strategic Leadership across Cultures: The GLOBE Study of CEO Leadership Behavior and Effectiveness in 24 Countries. SAGE Publications, Ltd .

S., S. S. (2001). Entrepreneurship as a field of research. 13-16.

Sang-Hoon Lee, Y. S. (2017). The Impact Of Job Demands And Resources On Job Crafting. The Journal of Applied Business Research .

Schaufeli, W. B. (2017). Applying the Job Demands-Resources model:A 'how to' guide to measuring and tackling workengagement and burnout. Elsevier, 120-132.

Schneider, B. (1975). Some relationship between job satisfaction and organizational climate. Journal of Applied Psychology, 318-328.

Schyns, B. (2004). Non-verbal elements of leadership behaviour. German Journal of Human Resources Research, 289-305.

Schyns, B. (2005). Implicit leadership theories: Essays and explorations. The Leadership Horizon Series.

Sebastian Aparicio, D. U. (2018). Entrepreneurship and regional economic growth in Antioquia: An empirical analysis. Economics and Business Letters, 84-91.

Shapero, A. (1982). The social dimensions of entrepreneurship. In C.A. Kent, D.L. Encyclopedia of Entrepreneurship.

Simsek, Z. J.-E. (2015). Strategic leadership and leaders in entrepreneurial contexts: a nexus for innovation and impact missed?. Journal of Management Studies, 464-478.

Sobia Ali, Y. A. (2014). Effect of Work Overload on Job Satisfaction Effect of Job Satisfaction on EmployeePerformance and Employee Engagement (A Case of Public Sector University of Gujranwala Division). International Journal Of Multidisciplinary Sciences And Engineering.

Stephan, U., \& Pathak, S. (2016). Beyond cultural values? Cultural leadership ideals and entreprenurship. Journal of Business Venturing, 1-19.

Stephen P. Robbins, T. A. (2007). Organizational Behavior. Pearson.

Süß, S. (2011). Work-Life-Balance von Freelancern zwischen Realität und Idealvorstellung Eine explorative Studie. Zeitschrift Für Personalforschung/German Journal of Research in Human Resource Management, 247-268.

Thornton, P. R.-S. (2011). Socio-cultural factors and entrepreneurialactivity: an overview. International Small Business Journal, 105-118.

Thurik, A. F. (2010). The entrepreneurial culture: guiding principles of the self-employed. Entrepreneurship and Culture. 


\section{Macrothink

Tiessen, J. H. (1997). Individualism, collectivism, and entrepreneurship: A framework for international comparative research. Journal of Business Venturing,.

Trembath, C. J.-L. (2017). Job resources and demands for expatriate academics Linking teacher-student relations, intercultural adjustment, and job satisfaction. Journal of Global Mobility: The Home of Expatriate Management Research.

Tung, R. L. (2019). Cross-Cultural Entrepreneurship: The Case of China. American Psychological Association.

Unwin-Hyman, R. G. (1991). Leadership and Information Processing: Linking Perceptions and Performance. Journal of Organizational Behaviour .

Van Hemmen, S. U. (2013). Charismatic leadership and entrepreneurial activity: an empirical analysis. Innovar, 53-66.

Vecchio, R. (2003). Entrepreneurship and leadership: common trends and common threads. Human Resource Management Review, 303-328.

Venkataraman, S. (1997). The Distinctive Domain Of Entrepreneurship Research. Advances In Entrepreneurship, Firm Emergence and Growth.

Vink, J. O. (2011). Psychologische energiebronnen voor bevlogen werknemers: Psychologisch kapitaal in het Job Demands-Resources model. Gedrag \& Organisatie, 101-120.

Warr, P. (1992). Age and occupational well-being. Psychology and Ageing.

Wegge, J. \&. (2006). Arbeitszufriedenheit, Emotionen bei der Arbeit undorganisationale Identifikation. In L. Fischer. Arbeitszufriedenheit, 11-36.

Welsch, H. \&. (1981). Inter-relationships between organizational commitment and job characteristics, job satisfaction, professional behaviour, and organizational climate. Human Relations, 1079-1089.

Welter, F. (2011). Contextualizing entrepreneurship - conceptual challenges and ways forward. Entrep. Theory Pract.

Widyaningrum, M. E. (2011). Influence Of Motivation And culture On Organizational Commitment And Performance of employee Of Medical Services. Journal of Medical.

Wynne W. Chin, G. M. (1998). The Partial Least Squares Approach to Structural Equation Modeling. Advances in Hospitality and Leisure .

Xanthopoulou, D. B. (2007). The role of personal resources in the job demands-resources model. International . Journal of Stress Management, 121-141.

Xenikou, A. S. (n.d.). Organizational culture and transformational leadership as predictors of business unit performance (Vols. Vol.21,No. 60, ). Jounal of managerial Psychology. 


\section{Macrothink}

Business Management and Strategy

ISSN 2157-6068

2019, Vol. 10, No. 2

Yavas, U. A., \& B, M. (1999). Satisfaction among expatriate managers: Correlates and consequences. Career Development International, 261-269.

Yucelt, U. (1982). Job satisfaction, absenteeism and workers choice in the Turkish industrial sector. The Journal of Psychology, 247-254.

Yuki, G. (1989). Leadership in organization. Englewood Cliffs.

Zhou, W. (2016). When does shared leadership matter in entrepreneurial teams: the role of personalitycomposition. International Entrepreneurship and Management Journal, 153-169.

\section{Copyright}

Copyright for this article is retained by the author(s), with first publication rights granted to the journal.

This is an open-access article distributed under the terms and conditions of the Creative Commons Attribution license (http://creativecommons.org/licenses/by/4.0/). 